Article

\title{
Spectrophotometric Detection of Glyphosate in Water by Complex Formation between Bis 5-Phenyldipyrrinate of Nickel (II) and Glyphosate
}

\author{
Aline Romero-Natale ${ }^{1}$, Ilaria Palchetti ${ }^{2}{ }^{\circledR}$, Mayra Avelar ${ }^{3,4}$, Enrique González-Vergara ${ }^{1}(\mathbb{D}$, \\ José Luis Garate-Morales ${ }^{5}$ and Eduardo Torres ${ }^{1, *(D)}$ \\ 1 Centro de Química, ICUAP, Benemérita Universidad Autónoma de Puebla, 14 Sur y Av. San Claudio, \\ Col. San Manuel, Puebla 72570, Mexico; aline_natale@hotmail.com (A.R.-N.); \\ enrique.gonzalez@correo.buap.mx (E.G.-V.) \\ 2 Dipartimento di Chimica, Università Degli Studi di Firenze, Via della Lastruccia 3, \\ 50019 Sesto Fiorentino (Fi), Italy; ilaria.palchetti@unifi.it \\ 3 Departamento de Ingeniería Celular y Biocatálisis, Instituto de Biotecnología Universidad Nacional \\ Autónoma de México, Av. Universidad 2001 Chamilpa, Cuernavaca 62210, Morelos, Mexico; \\ mavelarf@gmail.com \\ 4 Department of Biotechnology, Chemistry, and Pharmacy, University of Siena, Via A. Moro 2, \\ 53100 Siena, Italy \\ 5 Facultad de Ciencias Químicas, Benemérita Universidad Autónoma de Puebla, 14 Sur y Av. San Claudio, \\ Col. San Manuel, Puebla 72570, Mexico; jose.garate@correo.buap.mx \\ * Correspondence: eduardo.torres@correo.buap.mx; Tel.: +52-222-2295500 (ext. 7273)
}

Received: 26 February 2019; Accepted: 3 April 2019; Published: 6 April 2019

check for updates

\begin{abstract}
A spectrophotometric method for the determination of glyphosate based on the monitoring of a complex formation between bis 5-phenyldipyrrinate of nickel (II) and the herbicide was developed. The method showed a short response time (10 s), high selectivity (very low interference from other pesticides and salts), and high sensitivity (LOD $2.07 \times 10^{-7} \mathrm{~mol} / \mathrm{L}$, LOQ $9.87 \times 10^{-7} \mathrm{~mol} / \mathrm{L}$, and a $\mathrm{K}_{\mathrm{d}}$ from $1.75 \times 10^{-6}$ to $\left.6.95 \times 10^{-6} \mathrm{~mol} / \mathrm{L}\right)$. The Job plot showed that complex formation occurs with a 1:1 stoichiometry. The method was successfully applied in potable, urban, groundwater, and residual-treated water samples, showing high precision (0.34-2.9\%) and accuracy (87.20-119.04\%). The structure of the complex was elucidated through theoretical studies demonstrating that the nickel in the bis 5-phenyldipyrrinate forms a distorted octahedral molecular geometry by expanding its coordination number through one bond with the nitrogen and another with the oxygen of the glyphosate' carboxyl group, at distances between 1.89-2.08 $\AA$.
\end{abstract}

Keywords: environmental analysis; glyphosate; pesticides; phenyldipyrrinate; spectrophotometry; water pollution

\section{Introduction}

Glyphosate (N-(phosphonomethyl)glycine) (glyp) (Figure 1c) is the most intensively used herbicide worldwide because of its high effectiveness against annual grasses and aquatic weeds [1,2], with a global annual production estimated to be over 825,804 tons in 2014 [3]. Its use is allowed in agricultural, urban, and domestic activities [4], with the agricultural application being the most intensive one. The physical and chemical properties of glyp allow its distribution in the environmental compartments [5-7]. Furthermore, its chelating ability and the absorption constant in soil allows for its accumulation in several types of soils, mainly clays [8]; it is considered a stable compound in a pH range between 4 and 9 for hydrolysis and photolysis $[9,10]$. Glyp pollution in water, soil, and food samples are becoming 
a serious health concern [11-13]. In addition, its metabolite, aminomethylphosphonic acid (AMPA), also represents a potential danger to human and animal health $[14,15]$. Both compounds have been detected in groundwater and surface water in several countries $[6,16,17]$. As glyp has been labeled as a global pollutant $[18,19]$, assessing its presence in several environmental matrices is a vigorous area of research [20-22].

There are some analytical methods to determine the presence of glyp and the metabolite AMPA in different media, such as water, urine, and serums. The official method to determine glyp in water, the EPA-547 [23], requires herbicide derivatization post-column with o-phathdialdehyde (OPA) [24]. Other methods employ high-performance liquid chromatography (HPLC) [25] coupled with mass spectrometry [26-29], fluorescence [30], or capillary electrophoresis [31]. However, these methods are complex, as they require pre-treatment steps for the samples and lengthy analysis times, by which it is not always possible to analyze massive samples in situ [32,33]. Recently, other methods have been reported as alternative tools for monitoring environmental samples in situ with the added benefit of short analysis times. Furthermore, some other analytical methods can have remarkably low detection limits, such as spectrophotometric [34-37], electrochemical [38-40], and Enzyme-Linked ImmunoSorbent Assay (ELISA) techniques $[17,41]$. The development of new methodologies that are quick, sensitive, reproducible, and inexpensive represent a viable alternative to the current methods and instruments by allowing the analysis of a larger number of samples either on the field or at the lab [42-44].

Dipyrromethenes are chelators of bipyrrolic monoacids that can form stable complexes with metals due to their coordination chemistry and optic and fluorescent properties [45]. These ligands are structurally rigid, completely conjugated, and capable of functionalizing several positions of their structure $(1,5$, and 9) (Figure 1a). Hence, the coordination with metallic ions of meso-substituted dipyrromethenes (position 5) has been applied to the design of sensors. For instance, there is a study based on fluorescent probes on a boron dipyrromethene functionalized with a group of phenylboronic acids (BODIPY-PBAs) that can detect several monosaccharides in a concentration range of $0.1-100 \mathrm{mM}$, with good reproducibility and photostability [46]. In another study, an electrochemical biosensor was developed using a dipyrromethene- $\mathrm{Cu}(\mathrm{II})$ to determine the oligomeric form of amyloid beta (A $\beta 16-23)$ with concentrations in the range of $0.001-1.00 \mu \mathrm{M}$, which induces the neuronal dysfunction associated with Alzheimer's disease (AD) [47]. Another paper reported on the electroactive dipyrromethene-Cu biosensor to detect antibodies against avian influenza virus type H5N1 in hen sera [48].

In this study, the chelating capacity of glyp was exploited to bind the metallic moiety of the compound bis 5-phenyldipyrrinate of nickel (II) $\left(\mathrm{Ni}(\mathrm{PhDP})_{2}\right)$ (Figure 1b). Based on this molecular association, a method for glyp determination in several water samples is developed for the quantification of the complex formed between glyp and $\left(\mathrm{Ni}(\mathrm{PhDP})_{2}\right)$. The resulting method is fast, sensitive, accurate, and useful for the quantification of glyp in drinking, urban, and ground waters, and residual-treated wastewater.

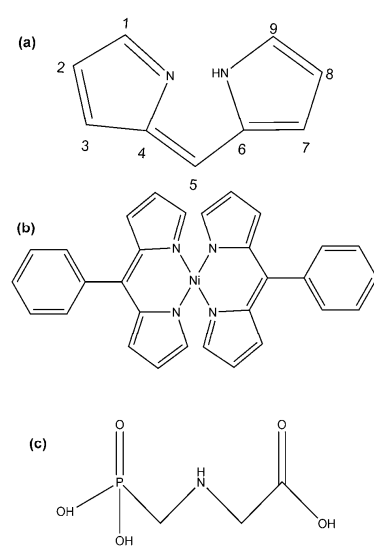

Figure 1. Chemical structure of (a) dipyrromethene ligand, (b) $\left(\mathrm{Ni}(\mathrm{PhDP})_{2}\right)$, and (c) glyp. 


\section{Materials and Methods}

\subsection{Reagents and Chemicals}

Glyphosate, silica gel, pyrrole, trifluoroacetic acid (TFA), benzaldehyde, triethylamine ( $\left.\mathrm{Et}_{3} \mathrm{~N}\right)$, and 2,3-Dichloro-5,6-dicyano-1,4-benzoquinone (DDQ) were from Sigma-Aldrich (St. Louis, MO, USA). The methylene chloride $\left(\mathrm{CH}_{2} \mathrm{Cl}_{2}\right)$, chloroform $\left(\mathrm{CHCl}_{3}\right)$, hexane, and methanol $\left(\mathrm{CH}_{3} \mathrm{OH}\right)$ were from Fermont (Monterrey, Mexico), and ethyl acetate was purchased from JT Baker (Center Valley, PA, USA). All the used reagents are analytical grade.

\subsection{Apparatus}

Electronic absorbance spectra measurements were obtained using a Varian Cary 50 spectrophotometer equipped with a xenon lamp (Australia). To perform electronic spectra measurements, quartz cuvettes $(1 \mathrm{~cm}$ path length) were used.

\subsection{Synthesis of the $\left(\mathrm{Ni}(\mathrm{PhDP})_{2}\right)$}

The procedure used by Brückner et al. [49] was followed to synthesize (Ni(PhDP) $)_{2}$. First, the 5-phenyldipyrrometane with benzaldehyde $(1 \mathrm{mmol})$, pyrrole $(1 \mathrm{mmol})$, and trifluoroacetic acid were synthesized. Then 2,3-Dichloro-5,6-dicyano-1,4-benzoquinone (1 mmol) was added and stirred for $30 \mathrm{~min}$ at room temperature. After that $\mathrm{Et}_{3} \mathrm{~N}(0.5 \mathrm{~mL})$ was added to the solution and stirred for another $30 \mathrm{~min}$ at room temperature. After the elimination of the solvent, the residue was dissolved in $\mathrm{CH}_{2} \mathrm{Cl}_{2}$, and the solution was filtered to remove precipitates. The solvent was removed, and the product was purified by short silica gel column chromatography using ethyl acetate as an eluent. The first eluted yellow fraction was evaporated to afford the crude product. Later, $2 \mathrm{mmol}$ of 5-Phenyldipyrromethene and $1 \mathrm{mmol}$ of nickel sulfate hexahydrate were dissolved in a mixture of $\mathrm{CHCl}_{3}$ and $\mathrm{CH}_{3} \mathrm{OH}$. The solution was agitated and heated under reflux for $6 \mathrm{~h}$, and then $0.5 \mathrm{~mL}$ of $\mathrm{Et}_{3} \mathrm{~N}$ were added and heated again under reflux for $4 \mathrm{~h}$. The solution was evaporated in a rotary evaporator until a dark brown solid was obtained. The dried remainder was dissolved in $\mathrm{CH}_{2} \mathrm{Cl}_{2}$ and $\mathrm{CH}_{3} \mathrm{OH}(1: 1)$, leaving it to slowly evaporate until crystals were obtained.

\subsection{The Interaction between the $\left(\mathrm{Ni}(\mathrm{PhDP})_{2}\right)$ Compound and Glyp}

The formation of the complex between $\left(\mathrm{Ni}(\mathrm{PhDP})_{2}\right)$ and glyp $\left(\mathrm{NiGlyp}(\mathrm{PhDP})_{2}\right)$ was followed by the changes in the electron absorption spectrum of $\left(\mathrm{Ni}(\mathrm{PhDP})_{2}\right)\left(1.08 \times 10^{-4} \mathrm{~mol} / \mathrm{L}\right)$ after the addition of glyp, in $1 \mathrm{~mL}$ of a $99 \%$ methanol, 1\% water solution. A calibration curve was developed, registering the absorbance changes of the new band at $362 \mathrm{~nm}$ at different glyp concentrations $\left(5.9 \times 10^{-7}\right.$ to $\left.1.1 \times 10^{-5} \mathrm{~mol} / \mathrm{L}\right)$.

\subsection{Complex Stoichiometry}

The Job method of continuous variation [50] was used to determine the stoichiometry of $\left(\operatorname{NiGlyp}(\mathrm{PhDP})_{2}\right)$. Two equimolar stock solutions were prepared and mixed in a way that the total concentration was kept constant $\left(5 \times 10^{-5}\right.$ and $1 \times 10^{-4} \mathrm{~mol} / \mathrm{L}$ for two different assays). The absorbance at $362 \mathrm{~nm}$ was measured after mixing for $10 \mathrm{~s}$ in a $1 \mathrm{~mL}$ reaction mixture $\left(99 \% \mathrm{CH}_{3} \mathrm{OH}-1 \%\right.$ water).

\subsection{Determination of the Dissociation Constant $(K d)$}

To determine the dissociation constant, a curve was constructed, in which the absorbance changes at $362 \mathrm{~nm}$ of $\left(\mathrm{Ni}(\mathrm{PhDP})_{2}\right)\left(3.6 \times 10^{-5}\right.$ and $1.08 \times 10^{-4} \mathrm{~mol} / \mathrm{L}$ for two different assays $)$ were monitored at different concentrations of glyp $\left(5.9 \times 10^{-7}\right.$ to $\left.2.3 \times 10^{-4} \mathrm{~mol} / \mathrm{L}\right)$, until its saturation was reached. The binding between the glyp and the $\left(\mathrm{Ni}(\mathrm{PhDP})_{2}\right)$ can be represented as Glyp $+\left(\mathrm{Ni}(\mathrm{PhDP})_{2}\right) \rightarrow$ $\left(\mathrm{NiGlyp}(\mathrm{PhDP})_{2}\right)$. 
The absorbance changes at $362 \mathrm{~nm}$ of the $\left(\mathrm{Ni}(\mathrm{PhDP})_{2}\right)$ complex at different concentrations of glyp were transformed to a percentage of change and adjusted to the one-site binding model [51] (Equation (1)) to determine $\mathrm{K}_{\mathrm{d}}$ :

$$
\Delta \mathrm{AG}=\Delta \mathrm{A}_{\max } \times \mathrm{K}_{\mathrm{d}} / \mathrm{G}_{0}
$$

where $\triangle \mathrm{AG}$ is the percentage of absorbance change at $362 \mathrm{~nm}$ upon adding each glyp concentration, $\Delta \mathrm{A}_{\max }$ is the maximum percentage of change $(100 \%)$ when the $\left(\mathrm{Ni}(\mathrm{PhDP})_{2}\right)$ is saturated with glyp, and $G_{0}$ is the total concentration of glyp. The reported values are the mean of the three replicates. The data were fit to the Hill equation using an iteration procedure following the Marquardt-Levenberg nonlinear least-squares algorithm, using Origin 8.0 software (Originlab Corporation, Northampton, MA, USA).

\subsection{The Analysis in Water Samples}

Four different water samples were analyzed to assess the potential of the methodology: potable, treated wastewater, urban, and groundwater, with each of them containing concentrations of glyp $\left(4.1 \times 10^{-6}\right.$ and $\left.5.9 \times 10^{-6} \mathrm{~mol} / \mathrm{L}\right)$ added intentionally. The analyses were carried out, in $1 \mathrm{~mL}$ of a $99 \%$ methanol, $1 \%$ water solution. Treated wastewater was filtered to remove suspended solids. The four water samples were stored at $4{ }^{\circ} \mathrm{C}$ until used and physicochemically characterized by following conventional methods: $\mathrm{pH}$, specific conductance, Chemical Oxygen Demand (COD), and Biochemical Oxygen Demand (BOD). Several anion and cation analyses were performed as well: $\mathrm{Ca}^{2+}, \mathrm{Fe}^{2+}, \mathrm{SO}_{4}{ }^{2-}$, $\mathrm{Mg}^{2+}, \mathrm{NO}^{3-}, \mathrm{NO}_{3}-\mathrm{N}, \mathrm{PO}_{4}{ }^{3-}, \mathrm{P}_{2} \mathrm{O}_{5}$, and free chlorine.

\subsection{Interfering Factors}

To identify possible interfering factors, various salts were added at the maximum concentrations found in the environmental water samples: $\mathrm{FeCl}_{3} \cdot 6 \mathrm{H}_{2} \mathrm{O}\left(6.6 \times 10^{-4} \mathrm{~mol} / \mathrm{L}\right.$ showed $\left.34 \mu \mathrm{s} / \mathrm{cm}\right), \mathrm{CaCl}_{2} \cdot 2$ $\mathrm{H}_{2} \mathrm{O}\left(9.8 \times 10^{-4} \mathrm{~mol} / \mathrm{L}\right.$ showed $\left.240 \mu \mathrm{s} / \mathrm{cm}\right), \mathrm{NaNO}_{3}\left(1.2 \times 10^{-2} \mathrm{~mol} / \mathrm{L}\right.$ showed $\left.140 \mu \mathrm{s} / \mathrm{cm}\right)$, and $\mathrm{MgCl}_{2} \cdot 6$ $\mathrm{H}_{2} \mathrm{O}\left(4.9 \times 10^{-5} \mathrm{~mol} / \mathrm{L}\right.$ showed $\left.8 \mu \mathrm{s} / \mathrm{cm}\right)$, as well as the phosphate salts $\mathrm{Na}_{2} \mathrm{PO}_{4} \cdot \mathrm{H}_{2} \mathrm{O}(140 \mu \mathrm{s} / \mathrm{cm})$, $\mathrm{Na}_{2} \mathrm{HPO}_{4} \cdot 7 \mathrm{H}_{2} \mathrm{O}(140 \mu \mathrm{s} / \mathrm{cm})$, and $\left(\mathrm{NH}_{4}\right)_{2} \mathrm{HPO}_{4}(146 \mu \mathrm{s} / \mathrm{cm})$ at a concentration of $4.1 \times 10^{-6} \mathrm{~mol} / \mathrm{L}$. Furthermore, other organophosphorus pesticides were tested: parathion $(0.85 \mu \mathrm{s} / \mathrm{cm})$, dimethoate $(0.82 \mu \mathrm{s} / \mathrm{cm})$, and diclophention $(0.80 \mu \mathrm{s} / \mathrm{cm})$, at a concentration of $4.1 \times 10^{-6} \mathrm{~mol} / \mathrm{L}$ for each one. The effect of the mix of salts $(420 \mu \mathrm{s} / \mathrm{cm})$ and pesticides $(0.88 \mu \mathrm{s} / \mathrm{cm})$ was also evaluated. For these studies, the assay time was $10 \mathrm{~s}$, the glyp concentration of $4.1 \times 10^{-6} \mathrm{~mol} / \mathrm{L}(0.81 \mu \mathrm{s} / \mathrm{cm})$ and the $\left(\mathrm{Ni}(\mathrm{PhDP})_{2}\right)$ concentration of $1.08 \times 10^{-4} \mathrm{~mol} / \mathrm{L}$ were set.

All the experimental assays were made in triplicate to assess the repeatability of the results. The statistical analysis of the data was performed using Origin Software V 8.0.

\subsection{Theoretical Structure of the (NiGlyp $\left.(\mathrm{PhDP})_{2}\right)$ Complex}

All calculations were performed using Density Functional Theory (DFT) [52,53] implemented in Gaussian 16 [54]. Geometry optimizations and frequency analysis were done in a vacuum with B3LYP functional and LANLD2Z basis sets. The local minima were identified with zero number of imaginary frequencies $(\mathrm{NIMAG}=0$ ). All calculations were made with no symmetry constraints.

\section{Results and Discussion}

\subsection{Synthesis and Characterization of the $\left(\mathrm{Ni}(\mathrm{PhDP})_{2}\right)$ Compound}

The $\left(\mathrm{Ni}(\mathrm{PhDP})_{2}\right)$ was successfully synthesized according to the procedure reported by Brückner et al. [49], and then it was characterized by UV-Vis $(\lambda \mathrm{nm}): 330,480$, and by mass spectrometry ${ }^{1} \mathrm{H}$ NMR spectroscopy based on the structural symmetry by signals for the aromatic protons. Xue et al. [55] characterized the $\mathrm{Ni}\left(\mathrm{PhDP}_{2}\right)$ with ${ }^{1} \mathrm{H} \mathrm{NMR}$ to have $\left(500 \mathrm{MHz}, \mathrm{CDCL}_{3}\right) \delta=9.426$ (s, $4, \alpha$-dipyrrin), 7.500 
(d, J = 2.5 Hz, 6H, Ar-H), 7483-7.331 (m, 8H, Ar-H, $\beta$-dipyrrin), 6.741 (d, J = 3.5 Hz, 4H, $\beta$-dipyrrin), which corresponds with what was reported.

\subsection{The Interaction between Glyp with $\left(\mathrm{Ni}(\mathrm{PhDP})_{2}\right)$}

As mentioned, the electronic absorption spectrum of $\left(\mathrm{Ni}(\mathrm{PhDP})_{2}\right)$ showed a characteristic band at $480 \mathrm{~nm}$, indicative of double-bond electron transition metals (Figure 2, line), which significantly increased in the presence of glyp $\left(1.1 \times 10^{-5} \mathrm{~mol} / \mathrm{L}\right)$; in addition, a new band at $362 \mathrm{~nm}$ was observed. The change in absorbance at $480 \mathrm{~nm}$, as well as the formation of a new absorption band, is attributed to the formation of a complex between both species, with measurable characteristics in the ultraviolet-visible boundary region. The complex formation was almost instantaneous, and no additional changes in the absorbance were detected after mixing and measuring immediately (average time 10 seconds).

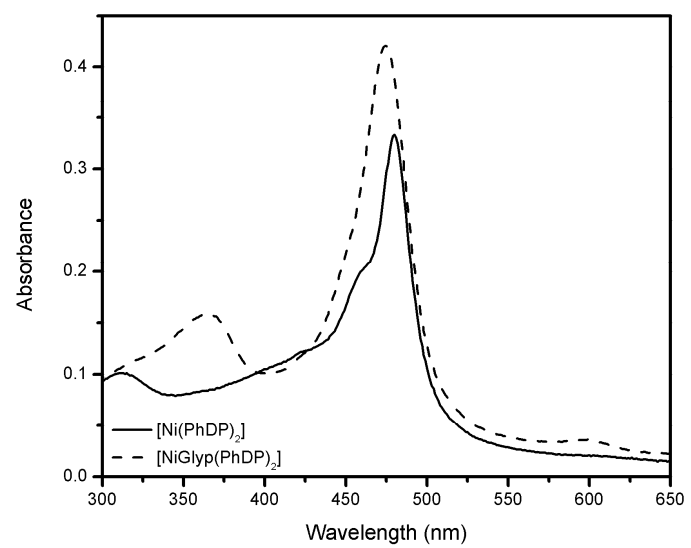

Figure 2. The electronic absorption spectrum of $\left(\mathrm{Ni}(\mathrm{PhDP})_{2}\right)\left(1.08 \times 10^{-4} \mathrm{~mol} / \mathrm{L}\right)$ in the absence (solid line) and the presence of glyp $\left(1.1 \times 10^{-5} \mathrm{~mol} / \mathrm{L}\right)$ (dotted line). Reaction conditions: $99 \%$ $\mathrm{CH}_{3} \mathrm{OH}-1 \%$ water.

Changes in the $\mathrm{pH}$ of the glyphosate solution, or the $\left(\mathrm{Ni}(\mathrm{PhDPD})_{2}\right)$ concentration, did not lead to improved results. Therefore, the $\mathrm{pH}$ of the water was kept at $\mathrm{pH} 7.0,\left(\mathrm{Ni}(\mathrm{PhDPD})_{2}\right)$ of $1.08 \times 10^{-4} \mathrm{~mol} / \mathrm{L}$, and incubation time of $10 \mathrm{~s}$.

As the purpose of the present study is the quantification of glyp in water samples, the dependence of the absorbance change on glyp concentration was determined. As can be seen in Figure 3, the absorbance at $362 \mathrm{~nm}$ was dependent on the glyp concentration, with a linear range from $5.9 \times 10^{-7}$ to $1.1 \times 10^{-5} \mathrm{~mol} / \mathrm{L}$ of glyp.

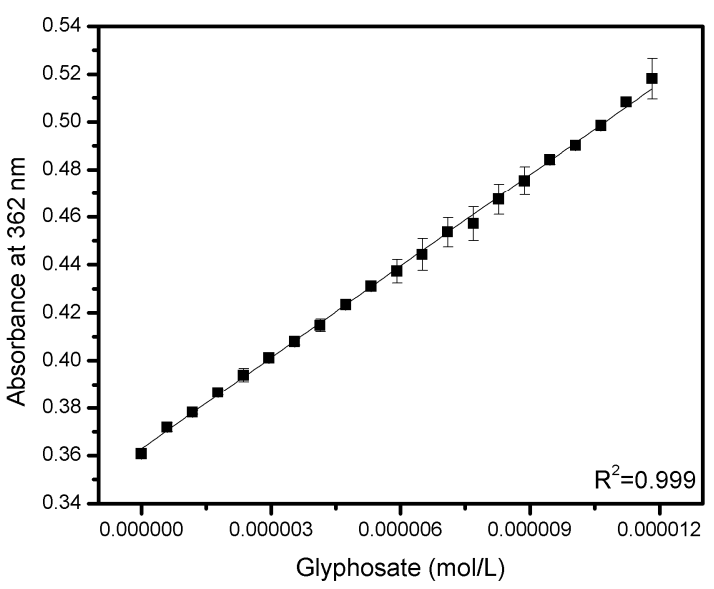

Figure 3. Calibration curve for the detection of glyp $\left(5.9 \times 10^{-7}-1.1 \times 10^{-5} \mathrm{~mol} / \mathrm{L}\right)$ based on the interaction with the compound $\left(\mathrm{Ni}(\mathrm{PhDP})_{2}\right)\left(1.08 \times 10^{-4} \mathrm{~mol} / \mathrm{L}\right)$. Reaction conditions: $99 \% \mathrm{CH}_{3} \mathrm{OH}-1 \%$ water. 
Equation (2) describes the relationship between the two variables, where $\mathrm{A}$ is the absorbance at $362 \mathrm{~nm}$, and $\mathrm{G}$ is the concentration of glyp $(\mathrm{mol} / \mathrm{L})$. The linear regression model fits the data very well, with a correlation coefficient higher than 0.99 . Also, other statistical results (analysis of variance and dynamic graphs, i.e., normal probability plot of the standardized residuals, scatter plots of the standardized residual against the predictor variable, and the index plot of the standardized residuals) support the quality of the linear model.

$$
A=0.0128 G+0.3629
$$

Using Equation (2), the detection limit (LOD) and the quantification limit (LOQ) were calculated. The LOD and the LOQ are numerically equal to 3 and 10 times the standard deviation of the mean absorbance of $\left(\mathrm{Ni}(\mathrm{PhDP})_{2}\right)$ without glyp (blank absorbance). Substituting these values in Equation (1), a LOD of $2.01 \times 10^{-7} \mathrm{~mol} / \mathrm{L}(34.98 \mu \mathrm{g} / \mathrm{L})$ and an LOQ of $9.87 \times 10^{-7} \mathrm{~mol} / \mathrm{L}(166 \mu \mathrm{g} / \mathrm{L})$ were determined. These values are good enough for glyp determination in drinking water in the USA, as the EPA Maximum Contaminant Level (the highest level of a contaminant that is allowed in drinking water) of $700 \mu \mathrm{g} / \mathrm{L}$ has been set [56], and, in principle, should be higher for environmental water samples. A study by Botta et al. [57] reported concentrations of glyp of $4.4 \times 10^{-7}-5.32 \times 10^{-7} \mathrm{~mol} / \mathrm{L}(75-90 \mu \mathrm{g} / \mathrm{L})$ in surface water. Therefore, it is possible to find high concentrations of glyp in environmental water that are within the LOD and LOQ obtained in this work. However, an improvement in detection is needed for application of the method in European countries, where the maximum level of glyp must not be higher than $0.1 \mu \mathrm{g} / \mathrm{L}$ [58]. In addition, our LOD and LOQ values are within the range of other alternative methods to detect the herbicide in a water sample (Table 1), with the advantages that the response time is shorter and there is no need for derivatization or the addition of reaction precursors.

Table 1. Comparison between other glyp determination in water.

\begin{tabular}{|c|c|c|c|}
\hline Method & LOD (mol/L) & LOQ (mol/L) & Remarks \\
\hline This method & $2.01 \times 10^{-7}$ & $9.87 \times 10^{-7}$ & $\begin{array}{l}\text { Rapid, effective, selective, facile, } \\
\text { and sensitive }\end{array}$ \\
\hline $\begin{array}{l}\text { Spectrophotometry with } \\
\text { multi-pumping flow } \\
\text { system [59] }\end{array}$ & $1 \times 10^{-6}$ & $3 \times 10^{-6}$ & $\begin{array}{l}\text { Rapid, effective and selective, but } \\
\text { needs pre-treatments }\end{array}$ \\
\hline $\begin{array}{l}\text { Fluorescence resonance } \\
\text { energy transfer [60] }\end{array}$ & $6 \times 10^{-7}$ & 1 & $\begin{array}{l}\text { Rapid, effective and selective, } \\
\text { but needs expensive equipment } \\
\text { Rapid, effective and selective, }\end{array}$ \\
\hline Electrochemical sensing [43] & $2 \times 10^{-6}$ & 1 & $\begin{array}{l}\text { but needs expensive equipment } \\
\text { and reagents }\end{array}$ \\
\hline Colorimetric sensor [35] & $6 \times 10^{-7}$ & 1 & $\begin{array}{l}\text { Effective and sensitive, but it requires } \\
\text { complex synthetizing steps }\end{array}$ \\
\hline
\end{tabular}

Note: ${ }^{1}$ Not reported.

\subsection{Stoichiometry}

For the complex stoichiometry, determination of the absorbance changes was plotted as a function of the mole fraction of the Glyp or $\left(\mathrm{Ni}(\mathrm{PhDP})_{2}\right)$ (Figure 4$)$ at two total concentrations. The Job plots show a triangular shape, which according to literature suggests a strong molecular interaction between the compounds; also, the maximum point in the curves takes place at 0.5 mole fraction, indicating that the molecular association occurs with stoichiometry 1:1 [50,61]. 

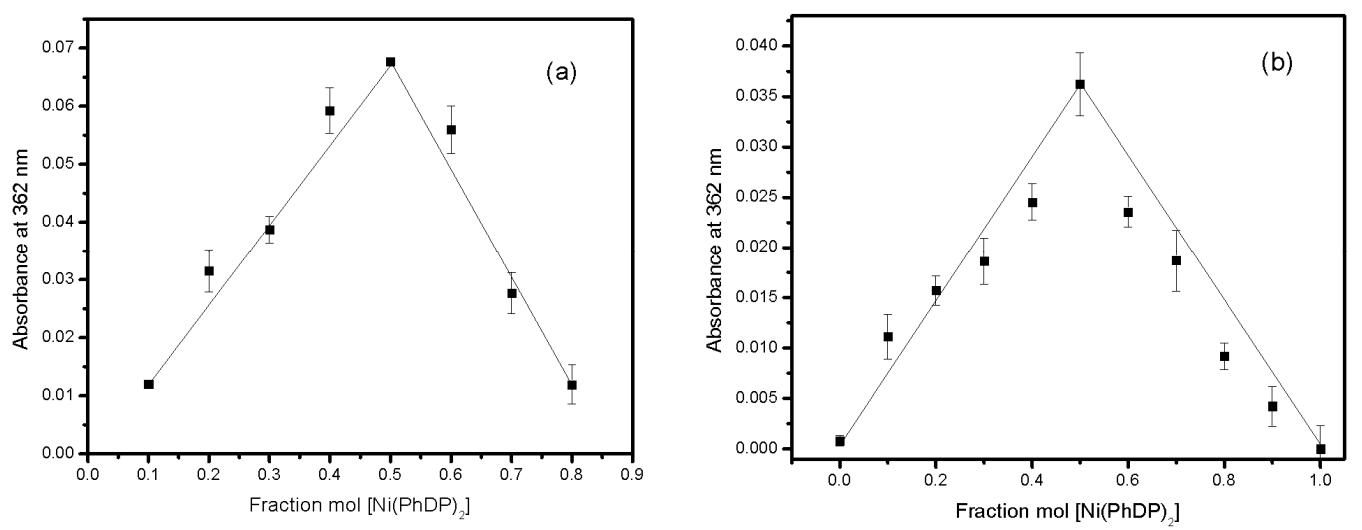

Figure 4. Job plot indicating the 1:1 stoichiometry for the (NiGlyp $\left.(\mathrm{PhDP})_{2}\right)$ complex, with a total concentration of (a) $5 \times 10^{-5} \mathrm{~mol} / \mathrm{L}$ and (b) $1 \times 10^{-4} \mathrm{~mol} / \mathrm{L}$.

\subsection{Dissociation Constant}

The $K_{d}$ was determined by fitting the data to the one-site binding model using nonlinear regression analysis (Figure 5). The obtained $\mathrm{K}_{\mathrm{d}}$ values were $1.75 \times 10^{-6}$ and $6.9 \times 10^{-6} \mathrm{~mol} / \mathrm{L}$ at two $\left(\mathrm{Ni}(\mathrm{PhDP})_{2}\right)$ concentrations $\left(3.6 \times 10^{-5}\right.$ and $\left.1.08 \times 10^{-4} \mathrm{~mol} / \mathrm{L}\right)$, which account for the affinity of the dipyrrinate ligand to glyphosate. According to Chenprakhon et al. and Pan et al. [51,62], a small $\mathrm{K}_{\mathrm{d}}$ value refers to a high binding affinity of the ligand to its target. Although the affinity values are three orders of magnitude lower compared to the antibody-antigen system, the dipirrinate ligand has the advantage that the analytic response does not need additional steps for separation and quantification, as in the immunoassay format.
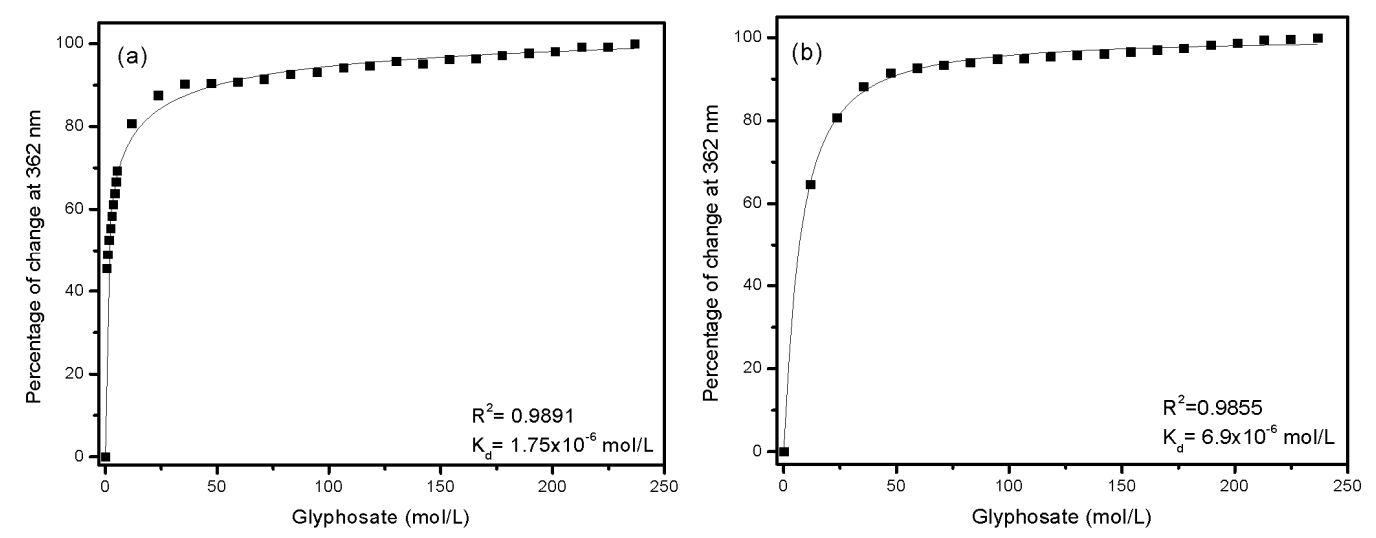

Figure 5. One site model fitting at (a) $1.08 \times 10^{-4} \mathrm{~mol} / \mathrm{L}$ of $\left(\mathrm{Ni}(\mathrm{PhDP})_{2}\right)$ and (b) $3.6 \times 10^{-5} \mathrm{~mol} / \mathrm{L}$ of $\left(\mathrm{Ni}(\mathrm{PhDP})_{2}\right)$ in the presence of glyp $\left(5.9 \times 10^{-7}\right.$ to $\left.2.36 \times 10^{-4} \mathrm{~mol} / \mathrm{L}\right)$.

\subsection{Method Selectivity}

The interference caused by other components that are usually present in water was determined to know the potential applicability of the method. It is well known that glyp can form strong coordination bonds with metal ions $\mathrm{Fe}^{2+}, \mathrm{Ca}^{2+}$, and $\mathrm{Mg}^{+2}[63,64]$. The results showed that the presence of individual cations and its mixture did not interfere significantly in the complexation of glyp with $\left(\mathrm{Ni}(\mathrm{PhDP})_{2}\right)$. The same set of experiments were carried out with other organophosphorus pesticides, which are continuously used in agriculture, such as parathion [65], dimethoate [66], and diclofenthion [67], as well as their mixtures. The absorbance values of the $\left(\mathrm{NiGlyp}(\mathrm{PhDP})_{2}\right)$ complex in the presence of the organophosphorus pesticides and its mixtures did not show an interference greater than $10 \%$ and thus are discarded as interferents. A mixture was tested between $\left(\mathrm{NiGlyp}(\mathrm{PhDP})_{2}\right)$ and AMPA because AMPA is frequently detected in water together with glyp $[68,69]$. Interestingly, the metabolite showed 
no additional change in the detection of glyp. Finally, different phosphate salts were tested, as it is already known that the phosphate ion may form complexes with nickel and other metals [70-72], which also showed no interference. All the assays suggest a good selectivity of the method (Table 2).

Table 2. Effects of the added salts, organophosphorus pesticides, and phosphates on the method selectivity.

\begin{tabular}{|c|c|c|c|}
\hline Compounds & Absorbance at $362 \mathrm{~nm}$ & Standard Deviation & Interference $(\%)^{1}$ \\
\hline $\begin{array}{c}\text { None } \\
\left(\mathrm{NiGlyp}(\mathrm{PhDP})_{2}\right)\end{array}$ & 0.42 & 0.012 & 0.0 \\
\hline \multicolumn{4}{|c|}{ Salts } \\
\hline $\mathrm{FeCl}_{3} \cdot 6 \mathrm{H}_{2} \mathrm{O}$ & 0.43 & 0.008 & 2.57 \\
\hline $\mathrm{CaCl}_{2} \cdot 2 \mathrm{H}_{2} \mathrm{O}$ & 0.41 & 0.008 & 0.19 \\
\hline $\mathrm{NaNO}_{3}$ & 0.42 & 0.007 & 0.78 \\
\hline $\mathrm{MgCl}_{2} \cdot 6 \mathrm{H}_{2} \mathrm{O}$ & 0.44 & 0.008 & 3.66 \\
\hline Mixture of salts & 0.45 & 0.010 & 5.49 \\
\hline \multicolumn{4}{|c|}{ Organophosphorus pesticides } \\
\hline Parathion & 0.42 & 0.012 & 1.47 \\
\hline Dimethoate & 0.45 & 0.011 & 4.28 \\
\hline Diclofenthion & 0.43 & 0.002 & 0.22 \\
\hline Mixture of pesticides & 0.46 & 0.002 & 7.51 \\
\hline \multicolumn{4}{|c|}{ Phosphates } \\
\hline $\mathrm{Na}_{2} \mathrm{PO}_{4} \cdot \mathrm{H}_{2} \mathrm{O}$ & 0.41 & 0.003 & 2.57 \\
\hline $\mathrm{Na}_{2} \mathrm{HPO}_{4} \cdot 7 \mathrm{H}_{2} \mathrm{O}$ & 0.41 & 0.003 & 2.75 \\
\hline$\left(\mathrm{NH}_{4}\right)_{2} \mathrm{HPO}_{4}$ & 0.42 & 0.008 & 0.81 \\
\hline Mixture of phosphates & 0.43 & 0.005 & 0.67 \\
\hline \multicolumn{4}{|c|}{ Metabolite of glyp } \\
\hline AMPA & 0.42 & 0.12 & 0.0 \\
\hline
\end{tabular}

\footnotetext{
${ }^{1}$ The percentage of interference was calculated, taking the absorbance of 0.42 obtained from the complex $\left(\mathrm{Ni}(\mathrm{PhDP})_{2}\right)$ $1.08 \times 10^{-4} \mathrm{~mol} / \mathrm{L}$ and glyp $4.1 \times 10^{-6} \mathrm{~mol} / \mathrm{L}$ as $0 \%$ of interference, minus the absorbance of the complex in the
} presence of interference between the absorbance of the complex, multiplied by one hundred.

\subsection{Analysis of Spiked Water Samples}

Table 3 shows the results of the physicochemical parameters of the four water matrices used to check the applicability of the proposed method. The parameter values are indicative of the different sources; as expected, treated wastewater shows the highest COD and BOD. The amount of dication metals was determined because of their possible interference behavior. No glyp was detected using the commercially available ELISA method (PN 500086) (Abraxis LLC, Warminster, PA, USA). 
Table 3. Physicochemical analysis of the different water matrices.

\begin{tabular}{|c|c|c|c|c|}
\hline \multirow{2}{*}{ Parameters } & \multicolumn{4}{|c|}{ Water Matrix } \\
\hline & Potable & Urban & Groundwater & Treated Wastewater \\
\hline $\mathrm{pH}$ & 7.00 & 7.00 & 7.00 & 7.00 \\
\hline Specific conductance $(\mu \mathrm{s} / \mathrm{cm})$ & 0.05 & 424.00 & 523.00 & 1448.00 \\
\hline Temperature $\left({ }^{\circ} \mathrm{C}\right)$ & 25.00 & 25.30 & 25.30 & 24.70 \\
\hline COD $(\mathrm{mg} / \mathrm{L})$ & 2.00 & 152.70 & 97.20 & 651.38 \\
\hline $\mathrm{BOD}(\mathrm{mg} / \mathrm{L})$ & 0.73 & 76.48 & 42.00 & 320.62 \\
\hline $\mathrm{Ca}^{2+}(\mathrm{mg} / \mathrm{L})$ & 20.00 & 75.00 & 115.00 & 145.00 \\
\hline $\mathrm{Fe}^{2+}(\mu \mathrm{g} / \mathrm{L})$ & 51.00 & 68.00 & 67.50 & 178.50 \\
\hline $\mathrm{SO}_{4}{ }^{2-}(\mathrm{mg} / \mathrm{L})$ & 0.00 & 27.50 & 40.00 & 90.00 \\
\hline $\mathrm{Mg}^{2+}(\mathrm{mg} / \mathrm{L})$ & 0.00 & 10.00 & 30.0 & 10.00 \\
\hline $\mathrm{NO}_{3}-\mathrm{N}(\mathrm{mg} / \mathrm{L})$ & 1.10 & 1.65 & 18.35 & 24.00 \\
\hline $\mathrm{NO}_{3}^{-}(\mathrm{mg} / \mathrm{L})$ & 5.00 & 82.75 & 99.45 & 104.00 \\
\hline $\mathrm{PO}_{4}{ }^{3-}(\mathrm{mg} / \mathrm{L})$ & 0.10 & 4.80 & 0.94 & 40.20 \\
\hline $\mathrm{P}_{2} \mathrm{O}_{5}(\mathrm{mg} / \mathrm{L})$ & 0.08 & 4.53 & 0.67 & 31.00 \\
\hline Free chlorine (mg/L) & 0.07 & 0.35 & 0.007 & 0.10 \\
\hline
\end{tabular}

Then, the samples were spiked with glyp $\left(4.1 \times 10^{-6}\right.$ and $\left.5.9 \times 10^{-6} \mathrm{~mol} / \mathrm{L}\right)$ and added to the $\left(\mathrm{Ni}(\mathrm{PhDP})_{2}\right)$ solution. The glyp concentrations in the samples were calculated using Equation (2).

The percentages of recovery vary between $87.20-119.04 \%$ (Table 4 ), which indicates good accuracy of the methodology. Furthermore, a high precision was obtained, as reflected by the coefficients of variation $(0.34-2.89 \%)$. Overall, it seems that the presence of several salts and metals at different concentrations did not affect the detection, and the method may be applied for different water sources. It is important to note that the LOD and LOQ reported here suggests that the method may be used for screening purposes in heavily polluted water samples, such as those in agricultural lands or treatment facilities, where the pollutants are concentrated. Regarding urban or groundwater, where pollutants are in lower concentrations, a preconcentration step should be necessary, as it is usually carried out with other methods.

Table 4. Detection of glyp in spiked water samples.

\begin{tabular}{ccccc}
\hline Water Matrix & $\begin{array}{c}\text { Glyp Added } \\
\left(\times \mathbf{1 0}^{-\mathbf{6}} \mathbf{~} \mathbf{~ o l} / \mathbf{L}\right)\end{array}$ & $\begin{array}{c}\text { Glyp Determined } \\
\left(\times \mathbf{1 0}^{-\mathbf{6}} \mathbf{~} \mathbf{m o l} / \mathbf{L}\right)\end{array}$ & $\begin{array}{c}\text { Coefficient of } \\
\text { Variation }(\%)\end{array}$ & Recovery (\%) \\
\hline \multirow{2}{*}{ Potable } & 4.10 & 3.72 & 2.89 & 89.58 \\
& 5.90 & 5.14 & 0.34 & 87.20 \\
\hline \multirow{2}{*}{ Urban } & 4.10 & 3.66 & 2.09 & 88.64 \\
& 5.90 & 5.32 & 0.61 & 89.97 \\
\hline \multirow{2}{*}{ Groundwater } & 4.10 & 4.02 & 2.38 & 96.49 \\
\multirow{2}{*}{ Treated wastewater } & 5.90 & 6.32 & 0.82 & 106.99 \\
\hline \multirow{2}{*}{} & 4.10 & 4.90 & 1.31 & 118.67 \\
\hline
\end{tabular}

\subsection{Theoretical Results}

To predict the possible complex between $\left(\mathrm{Ni}(\mathrm{PhDP})_{2}\right)$ and glyp quantum $(\mathrm{QM})$, calculations were undertaken, starting the geometry optimization of probable compounds at the DFT level.

The structure complex shown in Figure 6 is the most probable compound found for the reaction of $\left(\mathrm{Ni}(\mathrm{PhDP})_{2}\right)$ with glyp, where the nickel in the $\left(\mathrm{NiGlyp}(\mathrm{PhDP})_{2}\right)$ complex expands its coordination number from 4 to 6 with a nitrogen and an oxygen atom of the glyp' carboxyl group, at distances between 1.89-2.08 $\AA$ in a distorted octahedral molecular geometry. The calculated bond distances are reported in Table 5. As can be seen, the distance values are similar to those reported in experimental conditions in the literature $[55,70]$. 


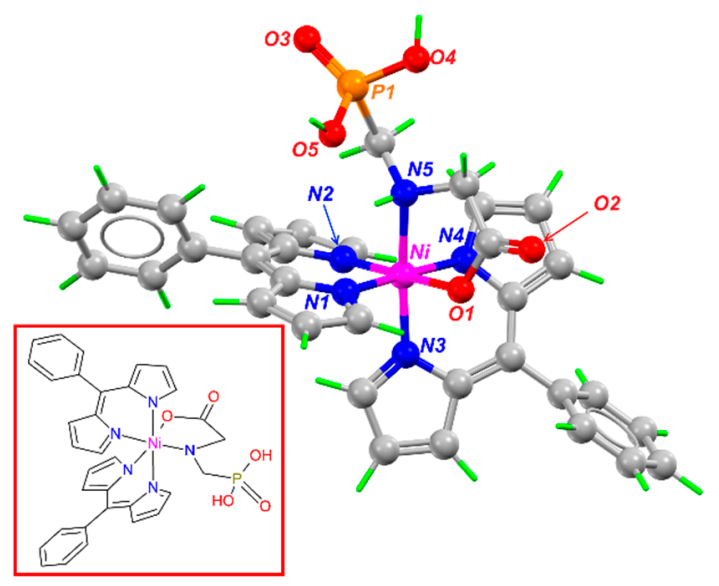

Figure 6. Optimized structure of the (NiGlyp $\left.(\mathrm{PhDP})_{2}\right)$ complex.

The oxygen atoms of phosphonic did not interact with the nickel atom because during the optimization this complex is not stable. Although it is known that the glyp could coordinate to nickel in a tridentated fashion, it appears that a heptacoordinate compound, in this case, is not stable. The shorter distance of the oxygen of the carboxyl group indicates a stronger interaction of the glyp with the title compound.

Table 5. Bond distances $(\AA)$ for the coordination atoms of the optimized structure $\left(\operatorname{NiGlyp}(\operatorname{PhDP})_{2}\right)$. Experimental values of $\left(\mathrm{Ni}(\mathrm{PhDP})_{2}\right)$ fragment $(\mathbf{a})$ and $\mathrm{Ni}(\mathrm{Glyp})_{2}(\mathbf{b})$ from the literature are provided for comparison $[55,70]$.

\begin{tabular}{|c|c|c|c|}
\hline \multicolumn{2}{|c|}{$\left(\mathrm{NiGlyp}(\mathrm{PhDP})_{2}\right)$} & \multicolumn{2}{|c|}{$\left(\mathrm{Ni}(\mathrm{PhDP})_{2}\right)(\mathrm{a})$ and $\mathrm{Ni}(\mathrm{Glyp})_{2}(\mathrm{~b})$} \\
\hline Bond & Distance (Å) & Bond & Distance (£) \\
\hline $\mathrm{Ni}-\mathrm{N}(1)$ & 1.93 & $\mathrm{Ni}-\mathrm{N}(\mathrm{a})$ & 1.88 \\
\hline $\mathrm{Ni}-\mathrm{N}(2)$ & 1.93 & $\mathrm{Ni}-\mathrm{N}(\mathrm{b})$ & 2.01 \\
\hline $\mathrm{Ni}-\mathrm{N}(3)$ & 1.94 & $\mathrm{Ni}-\mathrm{O}(\mathrm{b})$ & 2.05 \\
\hline $\mathrm{Ni}-\mathrm{N}(4)$ & 1.90 & & \\
\hline $\mathrm{Ni}-\mathrm{N}(5)$ & 2.08 & & \\
\hline $\mathrm{Ni}-\mathrm{O}$ & 1.89 & & \\
\hline
\end{tabular}

\section{Conclusions}

It has been possible to detect glyp by complex formation with stoichiometry 1:1, achieving a LOD of $2.07 \times 10^{-7} \mathrm{~mol} / \mathrm{L}$ and an LOQ of $9.8 \times 10^{-7} \mathrm{~mol} / \mathrm{L}$. The method developed assures data repeatability, high sensitivity, and quick detection (10 s).

The method was applied to determine known concentrations of glyp $\left(4.1 \times 10^{-6}\right.$ and $5.9 \times 10^{-6}$ $\mathrm{mol} / \mathrm{L}$ ) in potable and urban water, as well as groundwater and treated wastewater. The recovery percentages and the coefficients of variation obtained show good precision and accuracy of the method to be applied in environmental samples. The presence of the salts, other organophosphorus pesticides, and phosphates, as well as their mixtures in the water, do not interfere with glyp detection. The theoretical results show that the nickel of $\left(\mathrm{Ni}(\mathrm{PhDP})_{2}\right)$ forms coordination bonds with the nitrogen and oxygen atoms of glyp in a distorted octahedral molecular geometry.

Author Contributions: A.R.-N. carried out the experiment, analysis and wrote the first draft of the paper; E.T. contributed to conducting a research and investigation process, oversight and leadership responsibility; I.P. contributed to verification of experiments and revision of the first draft; J.L.G.-M. contributed in synthesis process and preparation of published work; M.A. contributed to application of computational study and creation of molecular structure; E.G.-V. analyzed the study data and editing of publisher work.

Funding: This research project was funded by the Ph.D. Grant Number 494272 from Consejo Nacional de Ciencia y Tecnología (CONACYT). 
Acknowledgments: Thanks to Marcela Ayala for allowing the use of UNAM supercomputing resources to perform the theoretical calculations, geometry optimizations, and frequency analysis (Project LANCAD-UNAM-DGTIC-293).

Conflicts of Interest: The authors declare no conflict of interest.

\section{References}

1. Dill, G.M.; Douglas, S.; Feng, P.C.C.; Kohn, F.; Kretzmer, K.; Mehrsheikh, A.; Bleeke, M.; Honegger, J.L.; Farmer, D.; Wright, D.; et al. Glyphosate: Discovery, development, applications, and properties. In Glyphosate Resistance in Crops and Weeds: History, Development, and Management; John Wiley \& Sons: Hoboken, NJ, USA, 2010; pp. 1-34. ISBN 9780470410318.

2. Grube, A.; Donaldson, D.; Kiely, T.; Wu, L. Pesticides Industry Sales, and Usage: 2006 and 2007 Market Estimates; USA Environment Protection Agency: Washington, DC, USA, 2011; pp. 1-41.

3. Benbrook, C.M. Trends in glyphosate herbicide use in the United States and globally. Environ. Sci. Eur. 2016, 28, 1-42. [CrossRef] [PubMed]

4. Steinmann, H.H.; Dickeduisberg, M.; Theuvsen, L. Uses, and benefits of glyphosate in German arable farming. Crop Prot. 2012, 42, 164-169. [CrossRef]

5. Battaglin, W.A.; Meyer, M.T.; Kuivila, K.M.; Dietze, J.E. Glyphosate and its degradation product AMPA occur frequently and widely in U.S. soils, surface water, groundwater, and precipitation. J. Am. Water Resour. Assoc. 2014, 50, 275-290. [CrossRef]

6. Rendón-Von Osten, J.; Dzul-Caamal, R. Glyphosate residues in groundwater, drinking water and urine of subsistence farmers from intensive agriculture localities: A survey in Hopelchén, Campeche, Mexico. Int. J. Environ. Res. Public Health 2017, 14, 596. [CrossRef] [PubMed]

7. Wijekoon, N.; Yapa, N. Assessment of plant growth promoting rhizobacteria (PGPR) on potential biodegradation of glyphosate in contaminated soil and aquifers. Groundw. Sustain. Dev. 2018, 7, 456-469. [CrossRef]

8. Okada, E.; Costa, J.L.; Bedmar, F.R.; Ramsier, C.; Kloepper, J.W. Changes in rhizosphere bacterial gene expression following glyphosate treatment. Sci. Total Environ. 2016, 553, 32-41.

9. Krüger, M.; Schledorn, P.; Schrödl, W.; Hoppe, H.-W.; Lutz, W.; Shehata, A.A.D. Adsorption and mobility of glyphosate in different soils under no-till and conventional tillage. Geoderma 2016, 263, 78-85.

10. Degenhardt, D.; Humphries, D.; Cessna, A.J.; Messing, P.; Badiou, P.H.; Raina, R.; Farenhorst, A.; Pennock, D.J. Dissipation of glyphosate and aminomethylphosphonic acid in water and sediment of two Canadian prairie wetlands. J. Environ. Sci. Health Part B Pestic. Food Contam. Agric. Wastes 2012, 47, 631-639. [CrossRef]

11. Mercurio, P.; Flores, F.; Mueller, J.F.; Carter, S.; Negri, A.P. Glyphosate persistence in seawater. Mar. Pollut. Bull. 2014, 85, 385-390. [CrossRef] [PubMed]

12. Byer, J.D.; Struger, J.; Klawunn, P.; Todd, A.; Sverko, E.D. Low-cost monitoring of glyphosate in surface waters using the ELISA method: An evaluation. Environ. Sci. Technol. 2008, 42, 6052-6057. [CrossRef]

13. Çetin, E.; Şahan, S.; Ülgen, A.; Şahin, U. DLLME-spectrophotometric determination of glyphosate residue in legumes. Food Chem. 2017, 230, 567-571. [CrossRef] [PubMed]

14. Newman, M.M.; Lorenz, N.; Hoilett, N.; Lee, N.R.; Dick, R.P.; Liles, M. Detection of Glyphosate Residues in Animals and Humans. J. Environ. Anal. Toxicol. 2014, 4, 1-5.

15. Zouaoui, K.; Dulaurent, S.; Gaulier, J.M.; Moesch, C.; Lachatre, G. Determination of glyphosate and AMPA in blood and urine from humans: About 13 cases of acute intoxication. Forensic Sci. Int. 2013, 226, $20-25$. [CrossRef] [PubMed]

16. Aparicio, V.C.; De Gerónimo, E.; Marino, D.; Primost, J.; Carriquiriborde, P.; Costa, J.L. Environmental fate of glyphosate and aminomethylphosphonic acid in surface waters and soil of agricultural basins. Chemosphere 2013, 93, 1866-1873. [CrossRef]

17. Mörtl, M.; Németh, G.; Juracsek, J.; Darvas, B.; Kamp, L.; Rubio, F.; Székács, A. Determination of glyphosate residues in Hungarian water samples by immunoassay. Microchem. J. 2013, 107, 143-151. [CrossRef]

18. Hu, Y.S.; Zhao, Y.Q.; Sorohan, B. Removal of glyphosate from aqueous environment by adsorption using water industrial residual. Desalination 2011, 271, 150-156. [CrossRef] 
19. Ruiz-Toledo, J.; Castro, R.; Rivero-Pérez, N.; Bello-Mendoza, R.; Sánchez, D. Occurrence of glyphosate in water bodies derived from intensive agriculture in a tropical region of southern Mexico. Bull. Environ. Contam. Toxicol. 2014, 93, 289-293. [CrossRef] [PubMed]

20. Martínez, M.A.; Ares, I.; Rodríguez, J.L.; Martínez, M.; Martínez-Larrañaga, M.R.; Anadón, A. Neurotransmitter changes in rat brain regions following glyphosate exposure. Environ. Res. 2018, 161, 212-219. [CrossRef] [PubMed]

21. Valle, A.L.; Mello, F.C.C.; Alves-Balvedi, R.P.; Rodrigues, L.P.; Goulart, L.R. Glyphosate detection: Methods, needs and challenges. Environ. Chem. Lett. 2019, 17, 291-371. [CrossRef]

22. Van Bruggen, A.H.C.; He, M.M.; Shin, K.; Mai, V.; Jeong, K.C.; Finckh, M.R.; Morris, J.G. Environmental and health effects of the herbicide glyphosate. Sci. Total Environ. 2018, 616-617, 255-268. [CrossRef] [PubMed]

23. USA Environmental Protection Agency. Method 547 Determination of Glyphosate in Drinking Water By Direct-Aqueous-Injection HPLC, Post-Column Derivatization, and Fluorescence Detection; USA Environmental Protection Agency: Washington, DC, USA, 1990; Volume 1.

24. Kaczyński, P.; ozowicka, B. Liquid chromatographic determination of glyphosate and aminomethylphosphonic acid residues in rapeseed with MS/MS detection or derivatization/fluorescence detection. Open Chem. 2015, 13, 1011-1019. [CrossRef]

25. Kim, M.; Stripeikis, J.; Iñón, F.; Tudino, M. A simplified approach to the determination of N-nitroso glyphosate in technical glyphosate using HPLC with post-derivatization and colorimetric detection. Talanta 2007, 72, 1054-1058. [CrossRef]

26. Guo, Z.X.; Cai, Q.; Yang, Z. Determination of glyphosate and phosphate in water by ion chromatography-Inductively coupled plasma mass spectrometry detection. J. Chromatogr. A. 2005, 1100, 160-167. [CrossRef]

27. Ibáñez, M.; Pozo, Ó.J.; Sancho, J.V.; López, F.J.; Hernández, F. Re-evaluation of glyphosate determination in water by liquid chromatography coupled to electrospray tandem mass spectrometry. J. Chromatogr. A 2006, 1134, 51-55. [CrossRef] [PubMed]

28. Lee, E.A.; Strahan, A.P.; Thurman, E.M. Methods of Analysis by the USA Geological Survey Organic Geochemistry Research Group -Determination of Glyphosate, Aminomethylphosphonic Acid, and Glufosinate in Water Using Online Solid-Phase Extraction and High-Performance Liquid Chromatography/Mass Sp; Department of the Interior Washington: Washington, DC, USA, 2002.

29. Ibáñez, M.; Pozo, Ó.J.; Sancho, J.V.; López, F.J.; Hernández, F. Residue determination of glyphosate, glufosinate and aminomethylphosphonic acid in water and soil samples by liquid chromatography coupled to electrospray tandem mass spectrometry. J. Chromatogr. A 2005, 1081, 145-155. [CrossRef] [PubMed]

30. Padilla-Alonso, D.J.; Garza-Tapia, M.; Chávez-Montes, A.; González-Horta, A.; Waksman de Torres, N.H.; Castro-Ríos, R. New temperature-assisted ionic liquid-based dispersive liquid-liquid microextraction method for the determination of glyphosate and aminomethylphosphonic acid in water samples. J. Liq. Chromatogr. Relat. Technol. 2017, 40, 147-155. [CrossRef]

31. Moraes, M.P.; Gonçalves, L.M.; Pereira, E.A. Determination of glyphosate and aminomethylphosphonic acid by capillary electrophoresis with indirect detection using pyridine-2, 6-dicarboxylic acid or 3, 5-dinitrobenzoic acid. Int. J. Environ. Anal. Chem. 2018, 98, 258-270. [CrossRef]

32. Botero-Coy, A.M.; Ibáñez, M.; Sancho, J.V.; Hernández, F. Improvements in the analytical methodology for the residue determination of the herbicide glyphosate in soils by liquid chromatography coupled to mass spectrometry. J. Chromatogr. A 2013, 1292, 132-141. [CrossRef] [PubMed]

33. Yoshioka, N.; Asano, M.; Kuse, A.; Mitsuhashi, T.; Nagasaki, Y.; Ueno, Y. Rapid determination of glyphosate, glufosinate, bialaphos, and their major metabolites in serum by liquid chromatography-tandem mass spectrometry using hydrophilic interaction chromatography. J. Chromatogr. A. 2011, 1218, 3675-3680. [CrossRef]

34. Chang, Y.; Zhang, Z.; Hao, J.; Yang, W.; Tang, J. A simple label-free colorimetric method for glyphosate detection based on the inhibition of the peroxidase-like activity of $\mathrm{Cu}(\mathrm{II})$. Sens. Actuators B Chem. 2016, 228, 410-415. [CrossRef]

35. De Almeida, L.K.S.; Chigome, S.; Torto, N.; Frost, C.L.; Pletschke, B.I. A novel colorimetric sensor strip for the detection of glyphosate in water. Sens. Actuators B Chem. 2015, 206, 357-363. [CrossRef] 
36. Rawat, K.A.; Majithiya, R.P.; Rohit, J.V.; Basu, H.; Singhal, R.K.; Kailasa, S.K. $\mathrm{Mg}^{2+}$ ion as a tuner for colorimetric sensing of glyphosate with improved sensitivity: Via the aggregation of 2-mercapto-5-nitrobenzimidazole capped silver nanoparticles. RSC Adv. 2016, 6, 47741-47752. [CrossRef]

37. Waiman, C.V.; Avena, M.J.; Garrido, M.; Fernández Band, B.; Zanini, G.P. A simple and rapid spectrophotometric method to quantify the herbicide glyphosate in aqueous media. Application to adsorption isotherms on soils and goethite. Geoderma 2012, 170, 154-158. [CrossRef]

38. Bettazzi, F.; Romero Natale, A.; Torres, E.; Palchetti, I. Glyphosate determination by coupling an immuno-magnetic assay with electrochemical sensors. Sensors 2018, 18, 2965. [CrossRef]

39. Sánchez-Bayo, F.; Hyne, R.V.; Desseille, K.L. An amperometric method for the detection of amitrole, glyphosate and its aminomethyl-phosphonic acid metabolite in environmental waters using passive samplers. Anal. Chim. Acta 2010, 675, 125-131. [CrossRef] [PubMed]

40. Songa, E.A.; Arotiba, O.A.; Owino, J.H.O.; Jahed, N.; Baker, P.G.L.; Iwuoha, E.I. Electrochemical detection of glyphosate herbicide using horseradish peroxidase immobilized on the sulfonated polymer matrix. Bioelectrochemistry 2009, 75, 117-123. [CrossRef] [PubMed]

41. Sanchís, J.; Kantiani, L.; Llorca, M.; Rubio, F.; Ginebreda, A.; Fraile, J.; Garrido, T.; Farré, M. Determination of glyphosate in groundwater samples using an ultrasensitive immunoassay and confirmation by on-line solid-phase extraction followed by liquid chromatography coupled to tandem mass spectrometry. Anal. Bioanal. Chem. 2012, 402, 2335-2345. [CrossRef]

42. Farkas, E.; Szekacs, A.; Kovacs, B.; Olah, M.; Horvath, R.; Szekacs, I. Label-free optical biosensor for real-time monitoring the cytotoxicity of xenobiotics: A proof of principle study on glyphosate. J. Hazard. Mater. 2018, 351, 80-89. [CrossRef] [PubMed]

43. Noori, J.S.; Dimaki, M.; Mortensen, J.; Svendsen, W.E. Detection of glyphosate in drinking water: A fast and direct detection method without sample pretreatment. Sensors 2018, 18, 2961. [CrossRef]

44. Vaghela, C.; Kulkarni, M.; Haram, S.; Aiyer, R.; Karve, M. A novel inhibition based biosensor using urease nanoconjugate entrapped biocomposite membrane for potentiometric glyphosate detection. Int. J. Biol. Macromol. 2018, 108, 32-40. [CrossRef]

45. Yamamura, M.; Albrecht, M.; Albrecht, M.; Nishimura, Y.; Arai, T.; Nabeshima, T. Red/near-infrared luminescence tuning of group-14 element complexes of dipyrrins based on a central atom. Inorg. Chem. 2014, 53, 1355-1360. [CrossRef] [PubMed]

46. Zhai, J.; Pan, T.; Zhu, J.; Xu, Y.; Chen, J.; Xie, Y.; Qin, Y. Boronic acid functionalized boron dipyrromethene fluorescent probes: Preparation, characterization, and saccharides sensing applications. Anal. Chem. 2012, 84, 10214-10220. [CrossRef]

47. Jargilo, A.; Grabowska, I.; Radecka, H.; Sulima, M.; Marszalek, I.; Wyslouch-Cieszyńska, A.; Dehaen, W.; Radecki, J. Redox-Active Dipyrromethene-Cu(II) Monolayer for Oriented Immobilization of His-Tagged RAGE Domains-the Base of Electrochemical Biosensor for Determination of A $\beta 16-23^{\prime}$. Electroanalysis 2013, 25, 1185-1193. [CrossRef]

48. Jarocka, U.; Sawicka, R.; Stachyra, A.; Góra-Sochacka, A.; Sirko, A.; Zagórski-Ostoja, W.; Sączyńska, V.; Porębska, A.; Dehaen, W.; Radecki, J.; et al. A biosensor based on electroactive dipyrromethene-Cu(II) layer deposited onto gold electrodes for the detection of antibodies against avian influenza virus type H5N1 in hen sera. Anal. Bioanal. Chem. 2015, 407, 7807-7814. [CrossRef] [PubMed]

49. Brückner, C.; Karunaratne, V.; Rettig, S.J.; Dolphin, D. Synthesis of meso-phenyl-4, 6-dipyrrins, preparation of their $\mathrm{Cu}(\mathrm{II}), \mathrm{Ni}(\mathrm{II})$, and $\mathrm{Zn}(\mathrm{II})$ chelates, and structural characterization of bis[meso-phenyl-4, 6-dipyrrinato]Ni(II). Can. J. Chem. 1996, 74, 2182-2193. [CrossRef]

50. Renny, J.S.; Tomasevich, L.L.; Tallmadge, E.H.; Collum, D.B. Method of continuous variations: Applications of job plots to the study of molecular associations in organometallic chemistry. Angew. Chem. Int. Ed. 2013, 52, 11998-12013. [CrossRef] [PubMed]

51. Chenprakhon, P.; Sucharitakul, J.; Panijpan, B.; Chaiyen, P. Measuring binding affinity of protein-ligand interaction using spectrophotometry: Binding of neutral red to riboflavin-binding protein. J. Chem. Educ. 2010, 87, 829-831. [CrossRef]

52. Hohenberg, P.; Kohn, W. The Inhomogeneous Electron Gas. Phys. Rev. 1964, 136, B864. [CrossRef]

53. Kohn, W.; Sham, L.J. Self-Consistent Equations Including Exchange and Correlation Effects *. Phys. Rev. 1965, 140, A1133-A1138. [CrossRef] 
54. Frisch, M.J.; Trucks, G.W.; Schlegel, H.B.; Scuseria, G.E.; Robb, M.A.; Cheeseman, J.R.; Scalmani, G.; Barone, V.; Petersson, G.A.; Nakatsuji, H.; et al. Gaussian 16; Revision B.01; Gaussian. Inc.: Wallingford, CT, USA, 2016.

55. Wang, Y.; Xue, Z.; Dong, Y.; Zhu, W. Synthesis and electrochemistry of meso-substitutes dipyrromethene nickel (II) complexes. Polyhedron 2015, 102, 578-582. [CrossRef]

56. United States Environmental Protection Agency. 2018 Edition of the Drinking Water Standards and Health Advisories Tables; United States Environmental Protection Agency: Washington, DC, USA, 2018.

57. Chevreuil, M.; Blanchoud, H.; Guery, B.; Moreau-Guigon, E.; Couturier, G.; Botta, F.; Alliot, F.; Fauchon, N.; Lavison, G. Transfer of glyphosate and its degradate AMPA to surface waters through urban sewerage systems. Chemosphere 2009, 77, 133-139.

58. Li, Z.; Jennings, A. Worldwide regulations of standard values of pesticides for human health risk control: A review. Int. J. Environ. Res. Public Health 2017, 14, 826. [CrossRef] [PubMed]

59. Silva, A.S.; Tóth, I.V.; Pezza, L.; Pezza, H.R.; Lima, J.L.F.C. Determination of glyphosate in water samples by multi-pumping flow system coupled to a liquid waveguide capillary cell. Anal. Sci. 2011, 27, 1031-1036. [CrossRef]

60. Yuan, Y.; Jiang, J.; Liu, S.; Yang, J.; Zhang, H.; Yan, J.; Hu, X. Fluorescent carbon dots for glyphosate determination based on fluorescence resonance energy transfer and logic gate operation. Sens. Actuators $B$ Chem. 2017, 242, 545-553. [CrossRef]

61. Hill, Z.D.; MacCarthy, P. Novel approach to Job's method: An undergraduate experiment. J. Chem. Educ. 1986, 63, 162. [CrossRef]

62. Pan, Y.; Sackmann, E.K.; Wypisniak, K.; Hornsby, M.; Datwani, S.S.; Herr, A.E. Determination of equilibrium dissociation constants for recombinant antibodies by high-throughput affinity electrophoresis. Sci. Rep. 2016, 6,1-11. [CrossRef]

63. Caetano, M.S.; Ramalho, T.C.; Botrel, D.F.; da Cunha, E.F.F.; de Mello, W.C. Understanding the inactivation process of organophosphorus herbicides: A DFT study of glyphosate metallic complexes with $\mathrm{Zn}^{2+}, \mathrm{Ca}^{2+}$, $\mathrm{Mg}^{2+}, \mathrm{Cu}^{2+}, \mathrm{Co}^{3+}, \mathrm{Fe}^{3+}, \mathrm{Cr}^{3+}$, and $\mathrm{Al}^{3+}$. Int. J. Quantum Chem. 2012, 112, 2752-2762. [CrossRef]

64. Ololade, I.A.; Oladoja, N.A.; Oloye, F.F.; Alomaja, F.; Akerele, D.D.; Iwaye, J.; Aikpokpodion, P. Sorption of Glyphosate on Soil Components: The Roles of Metal Oxides and Organic Materials. Soil Sediment Contam. 2014, 23, 571-585. [CrossRef]

65. Yola, M.L. Electrochemical activity enhancement of monodisperse boron nitride quantum dots on graphene oxide: Its application for simultaneous detection of organophosphate pesticides in real samples. J. Mol. Liq. 2019, 277, 50-57. [CrossRef]

66. Mondal, R.; Mukherjee, A.; Biswas, S.; Kole, R.K. GC-MS/MS determination and ecological risk assessment of pesticides in the aquatic system: A case study in Hooghly River basin in West Bengal, India. Chemosphere 2018, 206, 217-230. [CrossRef]

67. Ccanccapa, A.; Masiá, A.; Navarro-Ortega, A.; Picó, Y.; Barceló, D. Pesticides in the Ebro River basin: Occurrence and risk assessment. Environ. Pollut. 2016, 211, 414-424. [CrossRef] [PubMed]

68. Demonte, L.D.; Michlig, N.; Gaggiotti, M.; Adam, C.G.; Beldoménico, H.R.; Repetti, M.R. Determination of glyphosate, AMPA and glufosinate in dairy farm water from Argentina using a simplified UHPLC-MS/MS method. Sci. Total Environ. 2018, 645, 34-43. [CrossRef]

69. Fernandes, G.; Aparicio, V.C.; Bastos, M.C.; De Gerónimo, E.; Labanowski, J.; Prestes, O.D.; Zanella, R.; dos Santos, D.R. Indiscriminate use of glyphosate impregnates river epilithic biofilms in southern Brazil. Sci. Total Environ. 2019, 651, 1377-1387. [CrossRef] [PubMed]

70. Menelaou, M.; Dakanali, M.; Raptopoulou, C.P.; Drouza, C.; Lalioti, N.; Salifoglou, A. pH-Specific synthetic chemistry, and spectroscopic, structural, electrochemical and magnetic susceptibility studies in binary $\mathrm{Ni}(\mathrm{II})$-(carboxy)phosphonate systems. Polyhedron 2009, 28, 3331-3339. [CrossRef]

71. Peleka, E.N.; Mavros, P.P.; Zamboulis, D.; Matis, K.A. Removal of phosphates from water by a hybrid flotation-membrane filtration cell. Desalination 2006, 198, 198-207. [CrossRef]

72. Subramaniam, V.; Hoggard, P.E. Metal Complexes of Glyphosate. J. Agric. Food Chem. 1988, 36, $1326-1329$. [CrossRef]

(C) 2019 by the authors. Licensee MDPI, Basel, Switzerland. This article is an open access article distributed under the terms and conditions of the Creative Commons Attribution (CC BY) license (http://creativecommons.org/licenses/by/4.0/). 